\title{
History of the International Economy: The Bretton Woods System and its Impact on the Economic Development of Developing Countries
}

\author{
By Isaac O.C. Igwe*
}

The Bretton Woods conference held in July 1944 resulted in the creation of the World Bank (WB), the International Monetary Fund (IMF), and International Trade Organisation (ITO). It was primarily formed, in the words of John Maynard Keynes, to seek "a common measure, a common standard, a common rule applicable to each and not irksome to any." This article will examine this assertion in the light of Bretton Woods's system as a shift from the implied conventional-based economic cooperation of global states, to a rule-based multilateral economic cooperation of global communities.

Keywords: International Economy; Bretton woods; World Bank; IMF; ITO; Economic Development; Multilateral; Economic cooperation; Global Community; Developing Countries.

\section{Introduction}

The Bretton Woods conference of July 1944 set up the World Bank, International Trade Organisation (ITO), the International Monetary Fund (IMF) and post-war monetary arrangements by which the US dollar took the place of gold as the medium of international exchange. It may be seen that the primary function of the United States after World War II was establishing and maintaining the rules and instructions of a 'liberal' world economy. ${ }^{1}$ The pre-1914 gold system worked but emphasised the elements of the crisis that was brewing within the system during the 25 years before the outbreak of World War I via an increasing damaging collapse to its destruction in 1914.

World War I is seen as ephemeral turning point in the evolution of the world political economy and it is vital from the start to consider the general economic impact of that war upon the relative power position of the major countries. The structure of the pre-1914 international financial system was such that the gold stood as a key currency standard centred upon sterling, and this allowed Britain to act as a world monetary manager. ${ }^{2}$ As Cohen argues: "The classical gold standard was a sterling standard - hegemonic regime - in the sense that Britain not only dominated the international monetary order, establishing and maintaining the prevailing rules of the game, but also gave monetary relations whatever degree of inherent stability they possessed [...] It

*Ph.D. (Law), Researcher, Birkbeck, University of London, United Kingdom. Email: isaacigwe@hotmail.com.

${ }^{1}$ See Gilpin (1975) at 85.

${ }^{2}$ See Walter (1991) at 86. 
did not regard itself as responsible for global monetary stabilisation or as money manager of the world. Yet this is precisely the responsibility that was thrust upon it in practice $[\ldots]$, 3 .

Nonetheless, sterling was used internationally and tied closely with other larger and smaller national financial markets in London which gave Britain power to control the global monetary policy.

In this section, I will commence by considering the international monetary system's functioning between the period 1870-1914. The role which the United States played in the establishment of the post-war international monetary system will be examined. I will examine historically the ways in which specific international monetary arrangements both reflect and influence the distribution of political economic power among the capitalist countries, and use the international monetary history to illuminate the relationship between the western world and the third world in the period since World War II.

\section{The Golden Standard and Britain}

The period from 1870 - 1914 was the height of the gold standard, when all major nations lived within the rule of international monetary behaviour. It was a period seen as the 'golden age of international economic integration' since trade and financial flows grew considerably, and the global production system turned out more vertically unimpaired. ${ }^{4}$ The gold standard had grown steadily during the eighteenth and early nineteenth centuries as countries from a different metallic standard, silver, gold or bimetallic had adopted gold as their monetary base. ${ }^{5}$ In 1871 , the German Empire made gold its standard and in 1873 a parallel decision followed in the United States. By 1878 silver had been demonetised in France and virtually every other European country.

Thereafter gold was the basis of international payments among the leading countries until World War 1 transformed the international economy which the standard had served. ${ }^{6}$ Most major countries utilised the operation of the gold standard to fix the value of gold to their currencies. The countries permitted the flow of gold across their territories and as agreed at the established price, converted their currency at the agreed price. In turn, currencies exchange rates freely fluctuate as the demands of the market reaction.

The gold movement contributed to the balance of payments adjustment because the loss of a share of the country's gold supply would reduce the total supply of domestic money and credit. This, in turn, would deflate the economy and might result in a gradual improvement of the payment balance in the country. If a balance of payment surplus occurs in a country, the inflow of gold may lead to an acceleration of imports, a slowing of exports, and the elimination of the surplus.

\footnotetext{
${ }^{3}$ See Cohen (1977) at 81-82.

${ }^{4}$ See Chatterjee (1999).

${ }^{5}$ Yorkshire Bulletin of Economic and Social Research, May (1965) at 32-45.

${ }^{6}$ See Scammell (1985) at 103.
} 
The years from 1870-1914 were characterised by a high level of international monetary stability, especially in comparison to what would come later. The relative stability of the 'golden age' was based on the reality that Britain was a dominant figure in the organisation of the international monetary order. It was not the case of Britain providing the long term and short term capital needed to help the system going, but the evolution of the world economy in the nineteenth century was integrally related to Britain's own economic development. Kindleberger argues that the stability of the pre-war gold standard resulted from effective management by its lending member, Great Britain, and her agent, the Bank of England. ${ }^{7}$ The Bank of England is said to have stabilised the gold standard system standing in as the final hope of international lender to turn to. ${ }^{8}$

The gold standard method assured freedom of trade and the security of foreign investments, and because Britain benefited the most due to the openness of the world economy in the nineteenth century, and becomes logical for her to take the most responsibility to make the system work. When Britain faced a balance of payments deficit, the Bank of England simply raised the bank rate, increasing British domestic interest rates. This drew short-term capital. It often also slowed the pace of economic activity in Britain, resulting to increasing unemployment. ${ }^{9}$

Although, the mechanism of the gold standard functioned up until the event of World War I the dominance of Britain began to fade by the turn of the century. As Britain's economic lead seemed to diminish with the rise of American and German competition, so did the strength of the gold standard.

\section{The Unequal Rules of the Golden Standard}

One misconception of the gold standard concerned the process of balance of payment adjustment which was said to have depended primarily on changes of domestic price levels. ${ }^{10}$ The adjustment mechanism was that of the so-called price-specie flow mechanism which consisted of outflow of gold (specie) shrinking the money supply at home and deflating the level of domestic prices, and inflows expanding the money supply and inflating domestic prices. With regards to the process of balance of payment adjustment, Triffin had demonstrated that domestic price levels rarely played much role before $1914 .{ }^{11}$ In his view the process of adjustment depended at least as much on changes of domestic income and employment as on price changes. ${ }^{12}$

Considerably, the process depended on the role of international capital movements in adjusting to payments disequilibria which was more important than any role that the terms of trade may have played. Capital exporting countries

\footnotetext{
${ }^{7}$ See Kindleberger (1984) at 70.

${ }^{8}$ Ibid

${ }^{9}$ See Block (1978) at 13.

${ }^{10}$ See Payne (2005) at ch. 5-7.

${ }^{11}$ See Triffin (1986).

${ }^{12}$ Ibid
} 
could avoid the consequences of balance of payments deficits, domestic inflation or a possible threat to the gold convertibility of the local currency simply by slowing down investment abroad. The borrowing countries, on the other hand were far less able to control the rate of their capital imports which tended on the whole to swell in boom times and dry up hard times, contributing to further economic instability associated with their frequent dependence on one or a few items of raw material or export foodstuffs, subject to wide quantity and/or price fluctuations. Hence, there is high probability that the balance of payment of the so-called periphery will be maintained through the long period of enlarged capital imports from the industrialised Europe, but would eventually be paid back even at a stage of financial distortions and at the prevailing terms of trade. ${ }^{13}$

It was argued that Britain could slow the rate of capital export by raising the bank rate, thereby improving its own balance of payments at a relatively minimal cost to itself in the short run, whereas peripheral countries were more or less at the mercy of monetary management in the creditor countries. ${ }^{14}$ Triffin also argued that London's role in the financing of peripheral countries meant that bank rate increases had a favourable effect on Britain's term of trade in a downturn. ${ }^{15}$ By forcing a quicker liquidation of commodity stocks, this would exert downward pressure on the prices of Britain's major imports, to the detriment of commodity exporters in the periphery. ${ }^{16}$

The gold standard was arranged in a distinctly hierarchical fashion with the countries of the periphery at the bottom, the core countries above, and at the peak Britain. With this hierarchical structure when London raised its bank rate, capital was drawn from countries on the next financial tier. By the time countries on this next tier raised their bank rate, capital was being drawn from colonies, protectorates, and countries with underdeveloped financial markets, which lacked the power to neutralise this movement. It was then inevitable that the international financial transformation tension of this period be focused mostly in the periphery. Thus, it has been argued that the management of the gold standard was not impartial. ${ }^{17}$

The greater instability of the capital importing economies implied that the pre 1914 international monetary system benefits were to some extent concentrated in the core economies. This challenges not only the classical theory ${ }^{18}$ of the way the gold standard system operated, but also the idea that the international gold standard constituted an international public good, the benefits of which were equally available to all. The classical gold standard required the continued acquiescence of periphery countries in order to preserve a semblance of

\footnotetext{
${ }^{13}$ Ibid.

${ }^{14}$ See Triffin (1968) at 8.

${ }^{15}$ Ibid

16 Triffin (1968) at 9.

${ }^{17}$ See Eichengreen \& Flandreau (1999) at Editors' Introduction.

${ }^{18}$ Classical theory in economics historically can be traced from the works of Adam Smith in 1776, 'The Wealth of Nations' where he comprehensively analysed the economic ideology based on the phenomena of free markets and actions stems on individual self-interest in a laissez faire world.
} 
stability in the core, and also depended on the continued hegemony of Great Britain in the world's economic affairs.

\section{World Economic Instability in the Interwar Years}

In 1914 when World War 1 broke out, the gold standard collapsed as each countries began taking independent and disorderly steps resulting in the system being dismantled. The gold standard fixed exchange-rate mechanism was succeeded by its absolute opposite - an exchange rate system that was floating. In later years the currency values varied under the impact of wartime uncertainties.

At the post-World War 1, efforts were made to reinstate the gold standard system. However, restoring the gold standard was not a simple matter in the chaotic aftermath of World War 1. The immediate post war years were years of inflations that had occurred in almost all countries during and after the war. For advocates of gold standard restoration, the monetary chaos of the early twenties simply reinforced their views that Europe badly needed the stern discipline of the gold standard and fixed exchange rates.

At the Genoa Conference, the representatives of thirty-four nations including all the great powers except the United States met at Genoa from April 10 until May 1922. Britain dominated the conference, and the proposals of the conference were largely to economise on the use of gold. The Genoa Conference recommended the worldwide adoption of a gold-exchange standard in order to 'centralise and coordinate the demand for gold', to prevent the purchasing power of gold fluctuating which could occur where a number of countries compete simultaneously to secure the reserves. ${ }^{19}$ Central banks were urged to substitute foreign-exchange balances for gold in their reserves as a 'means of economising the use of gold'. ${ }^{20}$

In addition, a number of means were devised to build up national monetary reserves to levels at which the currencies could be stabilised in relation to gold. However, since total gold supplies appeared insufficient to provide adequately large reserves for all of the European countries, a deliberate effort was made to substitute currency reserves for gold. And some countries did significantly increase the share of their reserves held in the form of balances in foreign countries, particularly in Britain. ${ }^{21}$ Even with these measures, the stabilisation of European currencies in relation to gold dragged on through much of the 1920s.

It was expected by most countries that a return to the golden age must include returning to the exchange rates of pre-war period, which would appear unimaginable for the countries of continental Europe because inflation had reduced these currencies to a fraction of their pre-war values. However, some currencies, particularly the dollar, had remained unchanged in their gold values since before the war. This meant that severe deflation would be necessary before

\footnotetext{
${ }^{19}$ Currency Resolution of the Genoa Conference, as quoted in League of Nations, International Currency Experience, 1944, at.28

${ }^{20}$ Ibid

${ }^{21}$ See Block (1978) at 15.
} 
high inflation countries could stabilise at a new parity, or else their currencies would be widely undervalued.

The British choice to return to the pre-war parity, and the motivations for returning to the old price were primarily to restore levels of international financial confidence. It was thought that, while return to pre-war parity might well have serious domestic costs, it was necessary to bear these costs to set an example for other countries that were being pressured by the British to exercise greater monetary discipline. American cooperation and assistance were of great importance in making the British return to the old rate possible. For America, the stabilisation of the pound was seen to be in America's interest because it was a major step towards the stabilisation of the general European monetary situation, a prerequisite for the attainment of American financial and trading ambitions. ${ }^{22}$

The British, with this American assistance succeeded in re-establishing the pre-war parity in May 1925. This achievement was criticised by John Keynes. He argued that the pre-war parity was too high and would impose painful and useless deflation on the British economy. ${ }^{23} \mathrm{He}$ believed that the working class would successfully resist a direct reduction in its wages, so that even a high level of unemployment would fail to bring British wages and prices down to an internationally competitive level. He anticipated that the main results of the new parity would be intensification of class conflict in Britain and persistent unemployment. $^{24}$

Within a year of Britain re-establishing the gold standard nearly forty other countries had joined in the experiment, however the experiment did not last long. ${ }^{25}$ In 1931, the restored international gold standard collapsed when the British suspended the gold convertibility of sterling after the Bank of England had lost $£ 200$ million in gold and foreign exchange since July of that year. ${ }^{26}$ The restoration of an international monetary system with generalised currency convertibility had to wait until the late 1950s.

By 1919, due to wartime lending and a continuing current account surplus, the United States had become a net creditor in relation to the rest of the world. America's rise to net creditor status was due to United States credits to allies during the war, officially valued at more than $\$ 10$ billion in $1919 .{ }^{27}$ The bulk of these debts were owed by Britain, France and Italy, with France, Italy and Russia in turn owing Britain an amount not very much smaller. During the 1920s the United States was the major supplier of capital internationally, providing funds for relief and for currency stabilisation. Although, it emerged from the war as the world's leading industrial power, the United States resisted responsibility for the development of international economic relations. ${ }^{28}$ This manifestation of United States isolationism was due to the fear that other

\footnotetext{
${ }^{22}$ See Clarke (1967) at 72.

${ }^{23}$ See Keynes (1925).

${ }^{24}$ Ibid

${ }^{25}$ See Brown (1940) at $731-734$

${ }^{26}$ See Clarke (1967) at 216 - 218

${ }^{27}$ See Walter (1991) at 121.

${ }^{28}$ See Kindleberger (1973).
} 
countries would insist that the United State forgives their war debts to restore international economic stability.

Throughout the twenties, the United States insisted on repayment of the loans made to Britain, France, and other allies during the war. As long as France and Britain were obligated to repay these debts, they insisted that Germany pay to them the enormous reparations agreed on at Versailles. As the strain on the German economy of paying the reparations was serious, it threatened to disrupt the German political and economic order and weaken European stability in general. Hence, the American insistence on repayment of war debts was a major source of international instability in the 1920s and early 1930s. The United States emerged from World War 1 with little experience in managing the international system and little appreciation of the implications of its economic might for international stability.

After World War 1 there was no international regime, in the sense of rules and understandings adequate to guide international economic policies, developed in the 1920s. No institution was established to coordinate the stabilisation of European currencies. The depression of the 1930's highlighted the consequences of failing to formulate rules to act as a lead for the management of economic policies. ${ }^{29}$ The 1930's were a period of open economic warfare, ${ }^{30}$ as the absence of an international framework allowed countries to pursue opportunistic policies that compounded their neighbours. ${ }^{31}$ The great depression brought about rise to protectionism from different countries in a bid to protect their economies. In 1936 an air of cooperation was restored by the Tripartite Agreement among Britain, France, and the United States for mutual currency stabilisation. However, this was only the barest minimum that might have been done to restore consistency to international monetary relations. ${ }^{32}$ Genuine monetary reconstruction had to wait until after World War II. ${ }^{33}$

\section{The Bretton Woods System}

The difficulties of reconstruction after World War I influenced British and American officials from the start of World War II to begin planning for postwar monetary reconstruction. They saw the need to formulate rules and understanding to guide national polices following the war to aid the facilitation of common objectives. The International Monetary Fund (IMF) and the World Bank was launched as the two pillars of the new international financial system. They both originated in World War II following the United Nation Monetary and Financial Conference at Bretton Woods, New Hampshire in $1944,{ }^{34}$ with

\footnotetext{
${ }^{29}$ See Irwin (2012).

${ }^{30}$ See Higgs (2006).

${ }^{31}$ See Drinot \& Knight (2014).

${ }^{32}$ See Cohen (1977) at 86.

${ }^{33}$ See Bernanke (2009).

${ }^{34}$ See De Vries (1996) at 13.
} 
the participation of 44 nations which was ultimately concerned with formulating a regulatory international financial system.

The Charter of the IMF represented the post-war monetary order's written constitution and what later became known as the Bretton Woods system. The Bretton Woods system originated as a compromise between the rival ideology of Harry Dexter White of the United States Treasury and Lord Keynes of Britain. All agreed that the interwar experience had taught them several lessons, and there was a determination to prevent a repetition of previous mistakes. ${ }^{35}$ The IMF's Articles of Agreement contained the direct reflection of their consensus judgement.

The Bretton Woods conference basically resolved to create a number of strict codes of conduct that would frustrate one-sided currency devaluation that did not first agree on the fund and equally remove any form of international trade restriction that caused more harm than good during the inter-war period. On the other hand, the Bretton Wood proposed to put in place a mechanism that would enable the countries in financial crisis to reach out to international credits in order to avert serious economic collapse. ${ }^{36}$ The Bretton Woods system was designed to avoid the external constraint imposed on national economies by the gold standard, which had operated so disastrously in the interwar period. What was needed was flexibility to support nationally decided policies and to provide enough stability to avoid competitive devaluations.

One of the features of the Bretton Woods System which stood out was that the interwar period had demonstrated the disadvantages of freely fluctuating exchanges. ${ }^{37}$ Trade and investment was seen to be discouraged by the floating rates of the 1930s, while speculation and competitive depreciation was encouraged. The negotiators at Bretton Woods were determined to find some compromise between the two extremes and came up with the "pegged-rate" or "adjustable-peg" regime. ${ }^{38}$ Members intervened in the exchange market, limiting the fluctuations and declaring a par value for their currencies. The fluctuations maximum limits were one percent above or below parity. The members had the right to alter the par values to amend "fundamental disequilibrium" found in balance of payments.

Another feature of the Bretton Woods System was that if the exchange rates of participating governments were not to fluctuate freely, countries would need to be assured of an adequate supply of official monetary reserves. The experience of the interwar years (the gold shortage of the 1920s as well as the breakdown of fixed rates in the 1930s) was thought to have demonstrated the dangers of inadequate reserve volume. Hence, the second order of business at Bretton Woods was to ensure a supplementary source of reserve supply.

\footnotetext{
${ }^{35}$ See Cohen (1977) at $90-97$.

${ }^{36}$ See Pilling (1986) at ch. 5.

${ }^{37}$ See Nurkse (1944) at. 211

${ }^{38}$ Bretton Wood based on the dollar standard or adjustable peg system fixed exchange rate as the underlying principle of monetary stability based on dollar because of US held majority of currency and gold bullion reserves accumulated during the gold standard period; because of the dominance of US economy both in terms of productivity and output. Finally, the dollar was acceptable as both International medium of exchange and stable store of value
} 
Negotiators agreed that what they needed was some "procedure under which international liquidity would be supplied in the form of pre-arranged borrowing facilities". ${ }^{39}$ The negotiators came up with the IMF system which stood for different collections of national currencies and valued gold, a contribution made by every country. There was an obligation on the founding members to pay the Fund an assigned quota which consisted of the subscription amounting to equal amounts paid 25 percent in gold with the member's own currency accounting for the remaining 75 percent. Members of the IMF were required under the Articles of Agreement to peg their currencies to gold or to the dollar. The initial exchange rates and most changes made thereafter had to be approved by the IMF and this was on the condition that there was a "fundamental disequilibrium" faced by a country in its balance of payments. Through the Articles of Agreement there was an attempt to provide a source of reliable reserves of national currencies which was made available to the countries that experienced a deficit. The contribution made by each member to the currency pool was dictated by the member's quota which in turn prescribed what it could draw and its voting power in the IMF.

It was also agreed by all governments that it was important to prevent an economic warfare that occurred during the 1930s, and that there needed to be some sort of "code of action" to "guide international exchange adjustments". 40 At Bretton Woods, such a code was written into the obligations of Fund members. Governments were not permitted to participate in currency practices or exchange control regulation that was in any way discriminatory.

Finally, the governments accepted the need for an institution forum on monetary matters through international consultation and cooperation as "international monetary relations especially in the years before the Tripartite Agreement of 1936 suffered greatly from the absence of an established machinery or procedure of consultation." 41 The Fund would provide such a forum, and of all the achievements of Bretton Woods, this was potentially the most significant. For the first time ever, governments were formally committing themselves to the principle of collective responsibility for management of the international monetary order.

The Bretton Woods System has been characterised as a "much diluted form of a gold exchange standard". ${ }^{42}$ The US dollar continued to be pegged to gold at \$35 an ounce, and although changes in the dollar price of gold were permissible under Bretton Wood they were seen by most observers as undesirable and bordered on inconceivable. ${ }^{43}$ While America's gold reserves were comprised by its gold stock, other countries enjoyed the option of holding reserves in either dollar or gold, thus gold played a number of related roles in the post war gold-dollar standard, as Bretton Woods was sometimes called.

\footnotetext{
${ }^{39}$ See Nurkse (1994) at 218.

${ }^{40}$ See Nurkse (1944) at. 229.

${ }^{41}$ See Nurkse (1944) at $226-227$.

${ }^{42}$ See Dam (1982) at 133.

${ }^{43}$ See Eichengreen \& Flandreau (1999) at Editors' introduction.
} 
It did not occur to the negotiators at Bretton Woods that there might be any inherent defect in the structure of gold - exchange standard. The problem in the 1920s they felt, had not been the gold-exchange standard itself but a problem of management. ${ }^{44}$ To this effect the IMF was charged to provide in the Bretton Woods system the necessary machinery for multilateral cooperation, and thus the management problem would be solved and consistency in monetary relations maintained.

\section{The Dollar Crisis}

The nineteenth century witnessed the operation of classical gold standard embedded in the British capital strength while the system that emerged from Bretton Woods depended on the stability of the American capital, and the dominance of the United States facilitated the maintenance of the system ${ }^{45}$. However, the United States financial slope is as well critical to its later ruin. ${ }^{46}$ All major currencies were linked to gold through the dollar. Each country was concerned about the dollar parity of its currency which determines the level of profit available including the outcome of other foreign economic activities.

The Americans with their large stockpiles of gold were in a position to exchange dollars for gold, and this facilitated the link of gold to the whole currency system. As the United States bought and sold gold for the settlement of international transactions, any deficit with the rest of the world could be paid back in gold. The years preceding 1945 remained a continued flow of gold into the United States and this reflected the impoverishment of European State. The only available way of paying for American goods was with gold and by 1949 the gold-holding of the United States was equivalent to 70 percent of the entire capitalistic world reserves. ${ }^{47}$ Then onwards gold began moving in the opposite direction as the movement to United States stopped. America's gold reserve of the entire global holdings was reduced to 44 percent in 1960, and by 1972 at the time of the breakdown of Bretton Woods system, United States had less than 21 percent of aggregate control. ${ }^{48}$

The term 'dollar shortage' referred to the understanding that only the United States had the capability to shoulder the responsibility for global monetary stabilisation. The 'dollar storage' era was the bloom of America's dominance of international financial relations. Deficits in the dollar began in 1950, after a series of devaluation of European currencies in 1949 at the insistence of the

\footnotetext{
${ }^{44}$ See Cohen (1977) at 94.

45 See The US hegemony has been described as "embedded liberalism", a system that allowed more coercive forms of power utilised to entrench world capitalist order. This was exemplified in the US leadership in dealing with states and challenging communism through military interventionism.

${ }^{46}$ See Walter (1991) at 150.

${ }^{47}$ See Pilling (1986).

48 Ibid.
} 
United States. Towards the late 1950s, the balance of payment of America which previously was in excess became persistently deficit. ${ }^{49}$

The role of gold under the Bretton Woods System can be considered fewer than two categories - liquidity and adjustment. Liquidity under Bretton Woods System reduced highly liquid international reserves of gold, convertible foreign currency, and unconditional IMF credit. These reserves were needed in times of stress to defend a currency's dollar (and gold) parity. Although reserve requirements might not rise proportionately, the monetary expansion needed for economic growth required steadily increasing reserves. In practice, the balance of payments deficit during 1960s United States was the main source of incremental liquidity. Additional dollar holdings provided more than half the 22 per cent increase in international reserves between 1960 and $1967 .{ }^{50}$

The persistent deficits experienced by America took on another dimension after 1958, with the US balance of payments plunging in 1959 and 1960 to higher deficits. This led to the talk of "dollar glut" as opposed to "dollar shortage". The dollar glut was a result of the imbalance in persistent payments between the surplus countries of Europe, Japan and the United States. It was clear that the structure of Bretton Woods was coming under increasing strain, defects was forming in both the mechanism of liquidity creation and payment adjustment.

Overall, persistent payments deficits of the United States were criticised by America's trading partners. The French in particular criticised the United States for abusing its unique role within the Bretton Woods system, and engaged in sporadic efforts to change their holdings in dollar to gold after 1965. The French argued that the US obtained seigniorage ${ }^{51}$ by providing reserves to the rest of the world. The seigniorage might be used to increase spending on other nations' goods, purchase foreign companies, or finance military adventures. Kenen among others countered that the US had not sought this position but had been pushed into it by the demand abroad for additional reserve assets denominated in dollars. ${ }^{52}$

Triffin $^{53}$ argued that the negotiators at Bretton Woods had been too complacent about the gold-exchange standard. The problem was not simply one of management; rather it was one of structure - an inherent defect in the very concept of a gold-exchange standard. He had warned that the monetary system was intrinsically unstable. It could not rely on United States balance of payment deficits to meet the global need for reserves without eventually impairing

\footnotetext{
${ }^{49}$ See Cohen (1977) at 98-99.

${ }^{50}$ Statistics can be found in the International Monetary Fund's International Financial Statistics (various issues)

${ }^{51}$ Seigniorage means when a government makes profit from printing paper money or melting coins because the cost of making it is less than the market value of the money. It is the revenue the government derives by adding its stamp to piece of metal or ordinary piece of paper. Essentially, when the cost of producing the money is higher than the market value of the money in circulation, the government loses on seigniorage, but if the market value of the money in circulation is higher than the production cost of the money, the government gains more on seigniorage.

${ }^{52}$ See Kenen (1969).

${ }^{53}$ See Triffin (1960).
} 
confidence in United States commitment to sell gold for dollar because other countries' holdings of dollars would come to dwarf United States' gold stock. ${ }^{54}$

The main factor that sustained last century's gold standard was that the surplus on Britain's foreign account was ultimately self-sustaining. Britain as a major dominant manufacturing power had her foreign loan expanded especially after 1870, of which their recipients used it to purchase British goods. In addition, Britain's political control exercised over the colonial engine allowed for surpluses to be earned which could offset Britain's deficits that might be incurred from the increased exportation of capital. Britain's account with the rest of the world could be settled within the time period prior 1914, as her empire's trade surpluses which were mainly acquired through export products assisted in maintaining the outflow of British capital. ${ }^{55}$

The United States on the other hand was denied the luxury of direct taxation on an empire and the exportation of capital did not build up surpluses in trade, rather contributed in her receiving successful challenges to her role in the domination of the world economy. Kindleberger argued that there was instability in the world economic system, and it required a country to provide stability the way Britain performed during the nineteenth century up to 1913 , however the protection of national interest by various countries surfaced and led to the downfall of global interest. ${ }^{56}$ The Bretton Woods system took for granted that United States economic policy would be stabilising. Although America clearly had the best long-term record of price stability of any industrial country, the progressive deterioration of the United States served to undermine the global confidence in the convertibility of the dollar.

There existed three possibilities for the world economy to avoid a liquidity squeeze; a higher gold price achieved by a dollar devaluation and currency realignment abroad, creation by the IMF of new supplementary sources of liquidity, or abandonment of fixed parities in favour of generalised floating. Each of the options ultimately implied a reduced role for gold in the international monetary system. Kenen and others argued for a creation of supplementary reserves by the IMF. ${ }^{57}$ Keynes had had such an idea in mind when during wartime consultations; he proposed the creation of an international clearing union to provide unconditional drawing rights. However, the IMF that emerged from Bretton Woods was empowered to manage only a fixed pool of gold, dollars and other currencies which might be purchased by participants under certain restrictive conditions.

In the early 1960s the United States dollar came under a lot of pressure and evolved into continuous balance of payment deficit. The year 1968 witnessed the accumulation of $\$ 20$ billion worth of reserves by the world, taking into account the official control of gold by United States which was apparently inconvertible. ${ }^{58}$ The collection of dollars outside United States ensured the fact

\footnotetext{
${ }^{54}$ Ibid

${ }^{55}$ See De Cecco (1974).

${ }^{56}$ See Kindleberger (1973).

${ }^{57}$ See Kenen (1969).

${ }^{58}$ See Chatterjee (1999) at 11.
} 
that it was unavoidable for a depreciation of the dollar. At the Smithsonian Institution in Washington in December $1971,{ }^{59}$ the industrialised countries agreed on an exchange rate realignment involving a significant devaluation of the dollar. However, the US balance of payments was slow to improve after the Smithsonian Agreement, ${ }^{60}$ and the US Treasury concluded that a larger exchange rate change was needed. ${ }^{61}$

The final straw was a request by the British in August 1971 for the Federal Reserve to exchange some of the Bank of England's holdings in dollars for sterling, which was perceived in the US as the beginning of a general run on the dollar. The exchange rate alignments associated with the 1971 Smithsonian Agreement proved to be only a temporary expedient. ${ }^{62}$ On Sunday August 15, 1971, the US gold window was officially closed as a decision was unilaterally made by President Nixon marking the demise of the Bretton Woods system. ${ }^{63}$

\section{The Systems Development Impact on Developing Nations:}

Plausible as it may seem, the link connecting the British economy to the nineteenth century world economy and the relationship of the United States economy to the twentieth century world economy would be perfectly described as a relationship of dominance and power. ${ }^{64}$ Samir Amin argued that such an economy resembles the distinction between "extraverted" and "autocentric" national economies set for different reasons. In Amin's calculation, "autocentric" constitutes different parts of production, producers, customers, capital and labour contributes together as part of a single national economy while in contrast, 'extraversion' is not operating within the national remit alone, but extended its constituent elements on a global scale. ${ }^{65}$

The Bretton Woods institutions including the Truman's Doctrine ${ }^{66}$ formed the system of indirect imperialism under the 'pan Americana' or Roosevelt's 'pax Americana' (One Wordism) ${ }^{67}$ which later became the foundation of neo-

${ }^{59}$ See Volcker (2012); Also see De Vries (1976); See also International Monetary Fund. Annual Report of the Executive Directors for the Fiscal Year Ended April 30, 1973 Washington, DC: International Monetary Fund, 1973

${ }^{60}$ See online www.federalreservehistory.org/essays/smithsonian_agreement

${ }^{61}$ See Bordo (1983); See also Bordo \& Eichengreen (2008).

${ }^{62}$ See Eichengreen \& Flandreau (1999) at Editors' introduction.

${ }^{63}$ See Lownstein (2011); Also see Federal Reserve Bank of St. Louis (1971); Federal Reserve Bank of St. Louis (1947); Federal Reserve Bank of St. Louis (1972); Federal Reserve Bank New York (2007); Meltzer (2005).

${ }^{64}$ See Arrighi (2009).

${ }^{65}$ See Amin (1974) at 599.

${ }^{66}$ The early drafts prepared by state department staffers stressing an economic factors said that "Two great wars and an intervening world depression [...] have weakened the [capitalist] system almost everywhere except in the United States [...] If, by default, we permit free enterprises to disappear in other countries of the world, the very existence of our democracy will be gravely threatened". See McCornick (1989) at 98.

${ }^{67}$ See Schurmann (1974) at 5, 40-42, 67, 77. Roosevelt's vision of the new world order was an extension of his New Deal philosophy. The core of that philosophy was that only big, benign, and professional government could assure the people order, security and social justice...just as 
colonial age and extended till 1970. The unilateral action of the US in August 1971 under President Richard Nixon suspended the convertibility of the dollar and ended the rates regime negotiated by different countries at Bretton Woods. Thus a new form of international monetary cooperation was contemplated and Keynes' ambition for an international monetary authority able to penalise both 'deficit and surplus' nations, in order to balance the global economies, waned. As a result, states resolved to such groups as the G-7 and the G-5 to regulate international monetary policy. Since states were forced to float their currencies and exchange rates, the level of cooperation became uncertain. Amidst the financial crisis, the developed countries kept communication with other developed nations open and used IMF activities to discipline the developing countries or debtor nations. ${ }^{68}$ It was the informal nature of the system which made it concealed and arduous for people to place its intrinsic purpose. When this system collapsed under the name of the Bretton Wood, the United States reverted to military intervention to maintain balanced investment climate, resources and open market to the 'free world'.

Accordingly, from 1945 and 1970, the USA intervened militarily in Lebanon, Korea, Greece, Grenada, Dominican Republic and Vietnam. It was also connected with the destabilisation of regions in Iran, Guatemala, Cambodia, Turkey, South Korea, Lebanon, Cuba, Laos, Dominican Republic, El Salvador, Chile, Ghana, Zaire and Mali. ${ }^{69}$ This period of neo-colonialism came with its attributes which ranges from subjection to indirect imperialism, resource bondage, technology dependency which was identically shared by the new nations of Africa, Asia and Latin America. ${ }^{70}$ The experience in this period led to the convergence of the third world nations, emergence of development theories and counter theories to create new political and economic development ideology that would oppose the industrialised dominated world order. ${ }^{71}$

The Post World War II period witnessed the proposition for a more realistic economic coordination between states rather than a mere gentleman's agreement. An international organisation was badly needed, especially a global monetary system to enable states to rehabilitate their economies and as well enjoy a peaceful life. Thus the Bretton Woods conference was held and resulted in the creation of the World Bank, the International Monetary Fund and the International Trade Organisation (ITO).

These institutions were primarily formed, in the words of John Maynard Keynes, to seek 'a common measure, a common standard, a common rule applicable to each and not irksome to any'. ${ }^{72}$ Keynes concluded that 'It was a shift away from the tacit, conventional-based cooperation of central bankers to a sweeping, rule-based multilateral cooperation of states. ${ }^{73}$

the New Deal brought 'social security' to America, so 'one world' would bring political security to the entire world.

${ }^{68}$ See Braithwaite \& Drahos (2001) at 97-101.

${ }^{69}$ See Barakat (2004).

${ }^{70}$ See Igwe (2011a).

${ }^{71}$ See Hoogvelt (2001).

${ }^{72}$ See Moggeridge (1944) at 101.

${ }^{73}$ See Moggeridge (1944) at 103. 
The critical question is whether the creation of the Bretton Woods system was for 'common measure' and 'common standard' and was the rule applied for all and sundry without side lining some states? This writing takes the view that the rules embedded in the Bretton Woods institutions are protectionist, asymmetrical and impede balanced economic development. ${ }^{74}$ This writing has expressed numerous reasons to throw doubt on the statement of Keynes at the closing plenary session of the conference. Suffice it to say that this system was created as a mechanism for global trade and financial regulation, but it has not lived up to its calling as it has pursued bilateral trade and financial regulatory cooperation in the advanced world with a western hegemony in mind. ${ }^{75}$ The governance structure of the Bretton Woods system constitutes mostly industrialised countries which make vital decisions and form policies that are implemented by all as they represent the largest donors. Sometimes these decisions are made without adequate consultation with the developing countries. ${ }^{76}$ The aim of the international economic institutions was to foster the rebuilding of a shattered post-war economy and to elicit international economic cooperation and mutual trust among all nations. Critics are concerned about the impact of 'conditionality' imposed on countries that borrow from the institutions. ${ }^{77}$ Attachments to loan conditions are influenced by the 'Washington Consensus', i.e. liberalisation of trade, deregulation of currency and privatisation of nationalised industries. Worse still, these attached loan conditions are sometimes made without due consideration of the borrower's economic circumstances. To this extent they interfere with the borrower country's authority to govern its economy, since national economic policy is under the control of the institutions' rules. There are concerns about the type of development plan that these systems will lead to and apprehension as to the role of the Bretton Woods institutions in shaping development discourse through research and development programmes.

The IMF, the World Bank Articles of Agreement mandated it to 'the development of productive facilities and resources in less developed countries and the promotion of the balanced growth of International trade. ${ }^{78}$ In principle, the World Bank provides major source of finance for third world development through commercial assistance. But the truth is that the third world was starved of funds by controlling ministers who were mainly US. It was only in 1960 that 'soft loans' facility was established under UN's International Development Agency (IDA) because of the mounting pressure from UN and third world. The truth of the matter was that the third world did not receive much from World Bank in terms of development assistance. Conversely, European and Japanese economic recovery received Marshal Aids, US investment and other supportive protectionist concessions.

As the IMF's original Articles of Agreement made clear, the funds chief purpose was that of "promoting International monetary cooperation and exchange

\footnotetext{
${ }^{74}$ See Igwe (2011a).

75 Ibid.

${ }^{76}$ See Ikejiaku (2008).

${ }^{77}$ See Stiglitz \& Weiss (1981) at 393-410.

${ }^{78}$ See Brett (1985) at 73.
} 
stability, facilitating the expansion and balanced growth of International trade, and providing short term assistance to its members to enable them to correct maladjustments in their balance of payments without resorting to measures destructive of national, or International prosperity" ${ }^{79}$

In practice, IMF's assistance immediately after the post war time was very limited. The IMF similar to the World Bank was notably starved of funding. As a result, national balance of payment was taken care of by Marshal Aid and US export capital and by putting hold on dollar exchange until the achievement of surplus status. Moreover, 30 years after the $2^{\text {nd }}$ World War, there was general prosperity and growth among nations, and that made balance of payment challenges for many countries manageable independent of external assistance. At this period, for instance, British manufacturing trade was in surplus with relative decline in economy until 1983, Britain did not import manufactured goods. ${ }^{80}$

In 1970, the IMF 'conditionality' became predominant after the collapse of the dollar convertibility standard. The IMF 'Conditionality' gave it power to dictate the domestic policy of borrower nations. This became necessary after the post war boom in the 1970s and many nations witnessed serious balance of payment deficit that needed IMF intervention. ${ }^{81}$ At the behest of this balance of payment challenges, Britain in 1976 had no option than to borrow in order to maintain the strength of sterling and to contain a serious balance of payment deficit. This desperate act of Britain, brought in austerity programme by Labour Government, which misled Labour's interventionist and commitments policy on public spending and caused them to lose the 1979 general election to Conservative party.

The International Trade Organisation (ITO) established by Havana Charter of March 24, 1948 and officially known as the ("Final Act of the United Nations Conference on Trade and Employment") set out the International Trade rules and other International economic matters. The ITO was short lived and metamorphosed into the World Trade Organisation (WTO) which was established in 1995.

The WTO was formed after 7years of Uruguay Round of the General Agreement on Tariffs and Trade (GATT) to formalise and entrench free International trade as a model for International economic cooperation. WTO was regarded by many as the institution of 'global neoliberalism' because of its binding enforceable agreements on free trade and investment for all its members. ${ }^{82}$

Critics claim that its establishment is an attack to the mission of United Nations on Trade and Development (UNCTAD). Bello, argues that "the main drives behind the founding of the WTO were the twin needs to manage OECD trade rivalries more efficiently while 'containing the threat posed by the South

\footnotetext{
${ }^{79}$ See Lee (2002) at 284.

${ }^{80}$ See Strange (2011).

${ }^{81}$ Ibid.

${ }^{82}$ See Gill (1999).
} 
[as evident in the successful development of NICs in the 1950s-60s] to the prevailing global economic order". ${ }^{83}$

One of the primary structural reasons why trade failed to benefit the developing countries is in line with Lenin's radical emphasis and developed theories of Imperialism and unequal development created by unbalanced exchange and exploitation (Transfer of goods from South to North). Another structural reason is unbalanced terms of trade influenced by Raul Prebisch UNCTAD $1^{\text {st }}$ General Secretary in 1950 and 1960s, described as a theory of "bloodless but inexonerable exploitation", to describe the $3^{\text {rd }}$ world underdevelopment in the post - colonial political market freedom.

WTO could be regarded as an agent or tool of American imperialist body or better still, a pro capitalist organisation. ${ }^{84}$ International trade is dominated and controlled by greedy multinationals who rules with capitalist exploitation in terms of how dominance could be exercised on the developing countries markets. This depicts Leninist analysis of global capitalism when he wrote in 1916 that Imperialism is the highest stage of capitalism. All that is required in the economic matters of different countries debt is Washington Consensus neoliberal measures without considering the peculiarities of countries, thanks to Adams Smith invisible hands that mysteriously balance markets through the laissez-faire. ${ }^{85}$ The Special and Differential Treatment (S\&D) recognised by GATT in its early rounds for developing countries, demanded for less reciprocity and were structured in developmental terms. The move to a singletier system of rights and obligations signed in 1994 Uruguay Round requires developing countries to implement fully all the rules and commitments except in longer transition periods. This was only granted as a favour in return for something or quid pro quo for access to developing countries agriculture and textile market, as opposed to agricultural protectionism in the Industrialised nations. ${ }^{86}$

Against this background, the relationship of Bretton wood institutions and $3^{\text {rd }}$ world has not been easy. First, the IMF and World Bank are dominated by the US elitist and conservatives with the $3^{\text {rd }}$ world effectively excluded in area of decision making. Again, as the US dominated the International Political economy, IMF/WB has limited resources and power. Rhetorically, although Bretton Wood institutions continue to be global watch dogs, the IMF/WB are controlled by Washington which it represents and that regulates its action.

The idea of international monetary regulation created a structural problem: where the dominant currency in financial relations is the currency of a hegemon, temptation exists for that hegemon to use its dominant currency to look after its own domestic economic and political needs. Such a hegemon may use its domineering strength to flout the rules. In such a case, other states lack the power to discipline the hegemon breaching the order. John Keynes had proposed

\footnotetext{
${ }^{83}$ See Bello (2000) at 21.

${ }^{84}$ Stiglitz (2003).

${ }^{85}$ Smith (1723-1790) (2000).

${ }^{86}$ See Igwe (2011b).
} 
an international monetary authority to govern international finance. He advocated a central bank for the world and termed it an 'International Clearing Union' ${ }^{87}$

Against this background, the plan for an international monetary authority with balanced policy was not taken seriously in Bretton Woods by either the UK or the US (the hegemons).

With this in mind, a pragmatic development discourse becomes an essential paradigm to assuage the developed nations' unhealthy involvement in the developing nations' development strategies.

\section{Conclusion}

Pre-war economic events and the Bretton Woods institutions were characterised by asymmetry and global one sidedness. The era of the gold standard was framed in a hierarchical manner, favouring the core countries and leaving the periphery at the bottom. With this structure in place, London's bank rate was increased for the benefit of Britain's balance of payment deficit, which ultimately drew capital away from the poor countries towards the financial tier of the colonies. This brought about uncertainties and instabilities in monetary terms and led to the collapse of the gold standard. The management of the gold standard was at best exclusive - or a creation of a hegemon. Even when the gold standard was restored in Britain again, it did not last and America became the global net creditor for the restoration of an international monetary system, especially to European countries. This writing has shown through Lenin's classical imperialism theories that the causes of underdevelopment in the developing countries are external through their exploitation by the industrialised nations. The concentration of capital in the developed countries brings international economic inequality and domination.

The question remains whether the international trade network can allow balanced development amongst all participating countries of the world through the elimination of trade barriers and/or restrictions. So far in the long journey of the GATT/WTO it is difficult to ascertain fairness, transparency, equity and justice in its operation especially from the perspective of developing countries. These can only be fathomed through a hard look at the framework, policies, principles and practice of the world trade system as an organ of global economic governance. The Bretton Woods institutions should be an embodiment of development for all participating nations with clear structured international economic relations guided by rules. Those rules must be formulated by all and implemented with regard to ensuring improvement in standards of living and sustainable development for the developing countries.

${ }^{87}$ See Moggeridge (1944) at 10. 


\section{References}

Amin, S. (1974). The Accumulation of Capital on a World Scale: A Critique of the Theory of Underdevelopment. New York: Monthly Review Press.

Arrighi, G. (2009). The Long Twentieth Century, Money, Power, and the Origins of Our Times. London: Verso Books. New Edition.

Barakat, S. (ed.) (2004). After the Conflict: Reconstructions and Redevelopment in the Aftermath of the War. London: I.B. Tauris.

Bello, W. (2000). 'The Iron Cage: The WTO, the Bretton Woods Institutions and the South,' in Capitalism Nature Socialism, 11: 3-32.

Bernanke, B. S. (2009). Essays on the Great Depression. Princeton, N.J.: Princeton University Press.

Block, F.L. (1978). The Origins of International Economic Disorder: A Study of United States International Monetary Policy from World War II to the Present. Berkeley: University of California Press.

Bordo, M.D. \& B. Eichengreen (2008). 'Bretton woods and the Great Inflation', NBER Working Paper 14532, National Bureau of Economic Research.

Bordo, M.D. (1983).'The Bretton woods International Monetary System: A Historical Overview', in M.D. Bordo \& B. Eichengreen (eds.) A Retrospective on the Bretton Woods System: Lessons for International Monetary Reform, pp. 3-108. Chicago: University of Chicago Press.

Braithwaite J. \& P. Drahos (2000). Global Business Regulation. Cambridge, UK: Cambridge University Press.

Braithwaite J. \& P. Drahos (2001). Bretton Woods: Birth and Breakdown. In Global Business Regulation. Fathom. April

Brett, E.A. (1985). The World Economy since the War: The Politics of Uneven Development. London: Macmillan.

Brown, W.A., Jr. (1940). The International Gold Standard Reinterpreted 1914 - 1934. New York National Bureau of Economic Research.

Chatterjee, S. (1999). 'Unequal Partners: Globalisation in Retrospect and Prospect', Discussion Paper (Massey University, Department of Applied and International Economics), no. 99.05

Clarke, S.V.O. (1967). 'Central Bank Cooperation 1924 -31'. New York: Federal Reserve Bank of New York.

Cohen, B. J. (1977). Organising the World's Money. New York: Basic Books.

Dam, K.W, (1982). The Rules of the Game: Reform and Evolution in the International Monetary System. Chicago: University of Chicago Press.

De Cecco, M. (1974). Money and Empire. The International Gold Standard, 18901914. Oxford: B. Blackwell.

De Vries, M. G. (1976). The International Monetary Fund 1966 - 1971, The system under stress. Vol. 1, Narrative. Washington, DC: International Monetary Fund.

De Vries, M. G. (1996). 'The Bretton Woods Conference and the Birth of the International Monetary Fund', in O. Kirshner (ed.) The Bretton Woods - GATT System: Retrospect and Prospect After Fifty Years. New York: M.E. Sharp

Drinot, P. \& A. Knight. (eds.) (2014). The Great Depression in Latin America. Durham: Duke University Press.

Eichengreen, B. \& M. Flandreau (eds.) (1999). The Gold Standard in Theory and History, $2^{\text {nd }}$ ed. London \& New York: Routledge.

Federal Reserve Bank New York. (2007). 'Exchange Stabilization Fund’. May 2007. 
Federal Reserve Bank of St. Louis. (1947). International Monetary Policies: Post-war Economic Studies No. 7 September, 47.

Federal Reserve Bank of St. Louis. (1971). Federal Reserve Bank of New York Annual Report. March, 71.

Federal Reserve Bank of St. Louis. (1972). Stemming Inflation: The Office of Emergency Preparedness and the 90 day Freeze. Washington, DC. 15 August, 1972.

Gill, S. (1999). 'The Geopolitics of the Asian Crisis', in Monthly Review, 50 (10):1-10.

Gilpin, R. (1975). US Power and the Multinational Corporation. New York: Basic Books.

Higgs, R. (2006). Depression, War, and Cold war: Studies in Political Economy. Oxford University Press.

Hoogvelt, A. (2001). Globalization and the Post Colonial World: The New Political Economy of Development. $2^{\text {nd }}$ ed. UK: Palgrave Macmillan Education.

Igwe, I.O.C. (2011a). 'Globalisation and global economic governance: Reshaping the contours of International Trade Liberalisation.' PhD Thesis, School of Law, Birkbeck College University of London, UK.

Igwe, I.O.C. (2011b). 'The International Trade Law Context of Textile \& Clothing: Old Constraints and New Challenges,' in BIU Law Journals, Vol 1(1).

Ikejiaku, B.V. (2008). 'Africa Debt Crisis and IMF with a Case of Nigeria: towards theoretical explanation', in Journal of Politics and Law 1(4):2-7.

IMF. (1973). Annual Report of the Executive Directors for the Fiscal Year Ended April 30, (1973). Washington, DC: IMF.

Irwin, D.A. (2012). Trade Policy Disaster: Lessons from the 1930s. Cambridge, Mass: The MIT Press.

Kenen, P.B. (1969). 'The International Position of the Dollar in a Changing World', in International Organisation 23(3):705-718.

Keynes, M. J. (1925). Economic Consequences of Sterling Parity. New York: Harcourt, Brace and Co.

Kindleberger, C. P. (1973). The World in Depression, 1929 - 39. Berkeley: University of California Press.

Kindleberger. C.P. (1984). A Financial History of Western Europe. London: George Allen \& Unwin.

Lee, S. (2002). The International Monetary Fund: New Political Economy. Vol. 7(2). Carfax Publishing. pp.283-98.

Lownstein, R. (2011). 'The Nixon Shock', in Bloomberg Businessweek. 5 August, 2011.

McCornick, T. J. (1989). America's Half Century United States Foreign Policy in the Cold War. Baltimore, MD: Johns Hopkins University Press.

Meltzer, A. H. (2005). 'Origins of the Great Inflation', in Federal Reserve Bank of St. Louis Review 87, no. 2, Part 2 March/April 145 -75

Moggeridge, D. (ed.) (1944). The collected writings of John Maynard Keynes, London, Vol.26

Moggeridge, D. (ed.) (1980). The collected writings of John Maynard Keynes. London, Vol. 26.

Moggeridge, D. (ed.) (1994). The collected writings of John Maynard Keynes, London, Vol. 26.

Nurkse, R. (1944). International Currency Experience: Lessons of the Interwar period. Geneva: League of Nations. Ch. IX. (Review and Conclusion). April, 1944.

Payne, A. (2005). The Global Politics of Unequal Development. New York: Palgrave Macmillan.

Pilling, G. (1986). The Crisis of Keynesian Economics: A Marxist View. Progress Publishers. 
Scammell, W.M. (1965), 'The Working of the Gold Standard', Yorkshire Bulletin of Economic and Social Research, 17: 32-45.

Schurmann, F. (1974). The Logic of World Power, An Inquiry into the Origins, Currents and Contradictions of World Politics. New York: Pantheon.

Smith. A. (1723-1790)(2000). The Wealth of Nations/Adam Smith: Introduction by Robert Reich. Edited with notes, Marginal Summary and enlarged index by Edwin Cannan. New York: Modern Library.

Stiglitz, J. E. (2003). Globalisation and its Discontent. New York, London: W.W. Norton \& Company.

Stiglitz, J. E. \& A. Weiss, (1981). 'Credit Rationing in Markets with Imperfect Information', in American Economic Review, 71(3): 393-410.

Strange, G. (2011). 'Global Economic Governance Institutions and Developing World: From Bretton Woods to Beijing? Research-to-Teaching/Teaching-to-Research working Paper No. 7. Available at httpp://www.academia.edu/526184/Global_ Economic_Governance_Institutions_and_the_Development_World_fromBretton _Woods_to_Beijing.

Triffin, R. (1968). Gold and the Dollar Crisis. New Haven: Yale University Press.

Triffin, R. (1997). 'The Myth and Realities of the so-called Gold Standard' in B. Eichengreen \& M. Flandreau (eds.) The Gold Standard in Theory and History, $2^{\text {nd }}$ ed. London \& New York: Routledge, pp. 101-115.

Volcker, S.W.L.(2012). The Triumph of persistence. New York: Bloomsbury Press.

Walter, A. (1991). World Power and World Money: The Role of Hegemony and International Monetary Order. New York: St. Martin's Press.

Yorkshire Bulletin of Economic and Social Research - Journal Article, May 1965, pp. $32-45$. 
